\title{
THE EFFECTS OF SOIL CONDITIONERS ON TOTAL PROTEIN AND CRUDE FIBER CONCENTRATION IN SELECTED GRASS SPECIES
}

\author{
TRUBA, M..$^{*}$ - JANKOWSKI, K. ${ }^{1}$ - WIŚNIEWSKA-KADŻAJAN, B. ${ }^{1}-$ SOSNOWSKI, J. ${ }^{1}-$ \\ MALINOWSKA, E. ${ }^{1}-$ BARSZCZEWSKI, J. $^{2}$ \\ ${ }^{I}$ Department of Grassland and Green Areas Creation, Faculty of Natural Sciences, Siedlce \\ University of Natural Sciences and Humanities, Prusa 14 Street, 08-110 Siedlce, Poland \\ ${ }^{2}$ Institute of Technology and Life Sciences, Falenty, Al. Hrabska 3, 05-090 Raszyn, Poland \\ *Corresponding author \\ e-mail: milena.truba@uph.edu.pl \\ (Received 25 $5^{\text {th }}$ Jan 2018; accepted 25 ${ }^{\text {th }}$ Apr 2018)
}

\begin{abstract}
The aim of this study was to determine the influence of biological preparations and mineral fertilizers on total protein and crude fiber in Dactylis glomerata and Lolium perenne. The study was carried out in years 2011-2014 in three repetitions, on $3 \mathrm{~m}^{2}$ experimental plots. There were mineral, biological or both mineral and biological fertilization applied on the grass. Mineral fertilization included nitrogen, phosphorus, potassium. There were used three biological preparations named UGmax, Humus Active Papka and Eko-Użyźniacz in the studies. For both grass species Eko-Użyźniacz applied together with mineral fertilizers increased protein content in fodder. Application of Humus Active Papka with mineral fertilizers lowered crude fiber concentration in fodder. The highest concentration of total protein was in Dactylis glomerata and Lolium perenne from the plots where soil conditioners together with mineral fertilizers were applied. The most advantageous concentration of crude fiber was in Dactylis glomerata growing on the plot with Humus Active Papka together with mineral fertilizers applied, while in Lolium perenne on the plot with Eko-Użyźniacz applied, without mineral fertilizers.
\end{abstract}

Keywords: Dactylis glomerata, Lolium perenne, biopreparate, soil amendment, soil fertilizer, grass

\section{Introduction}

The vegetation of pastures and meadows consists mainly of grass, so important in ruminant nutrition, with Dactylis glomerata being one of the most nutritional species there (Stewart and Ellison, 2011; Billman et al., 2017; Jones et al., 2017). It contains a high amount of total protein, but a lot of substances, like crude fiber, lower its digestibility (Ellis et al., 2011; Tilvikiene et al., 2014; Cullen, 2017). Another popular grass species in permanent grasslands is Lolium perenne but, contrary to Dactylis glomerata, its total protein content is lower even if it is more digestible because of low fiber content (Turner, 2006a; Xiong et al., 2006; Robins and Lovatt, 2016,). According to many publications total protein content in fodder from permanent grasslands in Poland is diversified (Heinsoo et al., 2010; Jankowska-Huflejt and Wróbel, 2010; French, 2017). This content varies dependent on the species, its variety, the amount of nutrients in the soil (mainly nitrogen), the growing stage of the plant, the weather, and the grass cutting (Walter et al., 2012; Grant et al., 2014; Zielińska et al., 2014; Loaiza, 2017). Minimum content of total protein should range from 150 to $170 \mathrm{~g} \mathrm{~kg}^{-1}$. This amount of protein is indispensable for proper absorption of nutrients in the digestive system of dairy cows (Peeters, 2008; Grygierzec, 2012). Crude fiber has a big impact on nutritional value of the feed and animal health, and its concentration is dependent on the species, the variety of a plant, its age, the cutting, the fertilizers used, and precipitation 
(Mertens, 2002; Pozdisek et al., 2003; Arzani et al., 2004; Jankowska-Huflejt and Wróbel, 2010). For a balanced level of nutrient digestibility and energy value of feeds, the concentration of fiber should not exceed 28 - 30\% DM (Bumane, 2010).

Now there is a growing interest in organic farming and biological products such as fertilizers, soil conditioners, and similar substances approved by the Institute of Soil Science and Plant Cultivation (IUNG) in Puławy. This growing interest in biological products enhancing quality and quantity of crops is reflected in many publications (Sosnowski, 2012; Sosnowski et al., 2014; Sosnowski and Jankowski, 2015; Truba et al., 2017). However, not many studies are concerned with the effects of those products on the content of total protein and crude fiber in forage grass.

Considering the above, the aim of this paper is to study the effects of some soil conditioners on the content of total protein and crude fiber in Dactylis glomerata and Lolium perenne.

\section{Materials and methods}

\section{Characteristic of field site}

A randomised experiment in blocks replicated three times was set up in the experimental station of the Department of Grassland and Green Areas Creation of the University of Natural Sciences and Humanities in Siedlce in Poland $\left(52.169^{\circ} \mathrm{N}\right.$, $22.280^{\circ} \mathrm{E}$ ). According to the Polish soil classification system (Systematics of Polish Soils, 2011), the soil used in the experiment was the culture soils with the hortisole type, developed from loamy sand (Table 1).

Table 1. Soil granulometric composition

\begin{tabular}{c|c|c|c}
\hline \multicolumn{4}{c}{ Percentage share of soil fractions (diameter in mm) } \\
\hline $2.0-0.05$ & $0.05-0.002$ & $>0.002$ & Granulometric group \\
\hline 85 & 13 & 2 & $\mathrm{ps}$ \\
\hline
\end{tabular}

Based on the analysis performed at the Regional Chemical Station in Wesoła, it was found that the soil was of neutral $\mathrm{pH}(\mathrm{pH}$ in $1 \mathrm{n} \mathrm{KCL}=6.8)$, with a high content of humus $(3.78 \%)$, available phosphorus $\left(\mathrm{H}_{2} \mathrm{PO}_{4}^{-}-170 \mathrm{mg} \mathrm{kg}{ }^{-1}\right)$, magnesium $\left(\mathrm{Mg}^{2+}-84\right.$ $\left.\mathrm{mg} \mathrm{kg}{ }^{-1}\right)$, and moderate content of total nitrogen $\left(\mathrm{N}-1.3 \mathrm{~g} \mathrm{~kg}^{-1}\right)$ and available potassium $\left(\mathrm{K}^{+}-114 \mathrm{mg} \mathrm{kg}^{-1}\right)$.

\section{Characteristic of preparations used in experiment}

The aim of the experiment was to compare soil conditioners of the following trade names: UGmax, Eko-Użyźniacz, and Humus Active Papka, used separately and supplemented with NPK fertilizers. In the experiment, there were the following experimental units:

1. control (with no fertilizers),

2. UG (UGmax soil conditioner),

3. EU (Eko-Użyźniacz soil conditioner),

4. HA (Humus Active Papka soil conditioner),

5. NPK,

6. $\mathrm{UG}+\mathrm{NPK}$, 
7. $\mathrm{EU}+\mathrm{NPK}$,

8. $\mathrm{HA}+\mathrm{NPK}$.

The UGmax soil conditioner is an extract from compost, containing macronutrients $(\mathrm{N}, \mathrm{P}, \mathrm{K}, \mathrm{Mg}, \mathrm{Na}$ ) and micronutrients $(\mathrm{Mn})$. It also contains lactic acid bacteria, photosynthetic bacteria, Azotobacter, Pseudomonas, yeast, and Actinomycetes (Table 2). The microorganisms in the conditioner have a capacity of processing organic and natural fertilizers into compost and humus. These processes are conducive not only to the production of humus but also to improving soil structure, which in turn has a positive effect on water balance in the soil. In addition, the UGmax soil conditioner increases disease resistance, keeping plants healthy, but it also stimulates the development of the root system and supports the biological reduction of molecular nitrogen.

Humus Active Papka contains macronutrients (N, P, K, Ca, Mg), trace elements ( $\mathrm{Mn}$, $\mathrm{Fe}, \mathrm{Zn}, \mathrm{Cu}$ ), and active humus with useful microorganisms (Table 2). According to the manufacturer Humus Active Papka, among other beneficial effects, positively affects plant health as well as soil structure, and releases nutrients not readily available to plants.

Eko-Użyźniacz is extracted from bovine vermicompost and contains the main macronutrients $(\mathrm{N}, \mathrm{P}, \mathrm{K})$, microorganisms, and enzymes related to metabolism of earthworms (Table 2). This soil conditioner stimulates biological life in soil degraded chemically, mechanically, or biologically, and increases plant resistance to different stress factors.

Table 2. Ingredients of the soil conditioners

\begin{tabular}{c|c|c|c|c|c|c|c|c|c|c|c|c}
\hline \multirow{2}{*}{$\begin{array}{c}\text { Soil } \\
\text { conditioner }\end{array}$} & \multicolumn{5}{|c|}{$\begin{array}{c}\text { Macronutrients } \\
\left(\mathbf{g ~ k g}^{-1}\right)\end{array}$} & \multicolumn{5}{c|}{$\begin{array}{c}\text { Micronutrients } \\
\left(\mathbf{m g ~ k g}^{-1}\right)\end{array}$} & \multirow{2}{*}{$\begin{array}{c}\text { Microorganism and } \\
\text { others }\end{array}$} \\
\cline { 2 - 9 } & $\mathbf{N}$ & $\mathbf{P}$ & $\mathbf{K}$ & $\mathbf{C a}$ & $\mathbf{M g}$ & $\mathbf{N a}$ & $\mathbf{M n}$ & $\mathbf{F e}$ & $\mathbf{Z n}$ & $\mathbf{C u}$ & $\mathbf{M o}$ & \\
\hline $\begin{array}{c}\text { Humus } \\
\text { AHtive Papka } \\
\text { (HA) }\end{array}$ & 0.2 & 1.3 & 4.6 & 3.0 & 0.5 & - & 15 & 500 & 3 & 1 & - & $\begin{array}{c}\text { Active humus with useful } \\
\text { microorganisms }\end{array}$ \\
\hline $\begin{array}{c}\text { Eko- } \\
\text { Użźniacz } \\
\text { (EU) }\end{array}$ & 0.6 & 0.3 & 0.7 & - & - & - & - & - & - & - & - & $\begin{array}{c}\text { Endo micorhizza, fungi, } \\
\text { bacteria, enzymes of } \\
\text { earthworms }\end{array}$ \\
\hline $\begin{array}{c}\text { UGmax } \\
\text { (UG) }\end{array}$ & 1.2 & 0.2 & 2.9 & - & 0.1 & 0.2 & 0.3 & - & - & - & - & $\begin{array}{c}\text { Lactic acid bacteria, } \\
\text { photosynthetic bacteria, } \\
\text { Azotobacter, } \\
\text { Pseudomonas, yeast, } \\
\text { Actinomycetes }\end{array}$ \\
\hline
\end{tabular}

The above biological soil conditioning products were applied in the experiment every year in spring at the following doses: UGmax - 0.6 $\mathrm{L} \mathrm{ha}^{-1}$, Eko-Użyźniacz - $15 \mathrm{~L} \mathrm{ha}^{-1}$, and Humus Active Papka - $50 \mathrm{~L} \mathrm{ha}^{-1}$.

Mineral fertilizers with nitrogen, phosphorus, and potassium (NPK) were applied at the following doses: $\mathrm{N}-150, \mathrm{P}\left(\mathrm{P}_{2} \mathrm{O}_{5}\right)-80$, and $\mathrm{K}\left(\mathrm{K}_{2} \mathrm{O}\right)-120 \mathrm{~kg} \mathrm{ha}^{-1}$. Mineral nitrogen was supplied in the form of ammonium nitrate $\left(\mathrm{NH}_{4} \mathrm{NO}_{3}\right)$, phosphorus in the form of granulated triple superphosphate $\left(\mathrm{Ca}\left(\mathrm{H}_{2} \mathrm{PO}_{4}\right)_{2}\right)$, and potassium as high 
percentage potassium salt $(\mathrm{KCl})$. Phosphorus was applied once a year in spring, while potassium and nitrogen were used in three doses, before the growing season and before the second and third cuttings.

\section{Plant material and analysis}

The above products were tested on two grass species: Dactylis glomerata of the Bora variety and Lolium perenne of the Info variety, sown in the autumn of 2011 according to the standards of 18 and $23 \mathrm{~kg} \mathrm{ha}^{-1}$, respectively. The area of the experimental plot was $3 \mathrm{~m}^{2}$.

During the three-year experiment in each growing season the grass was harvested three times with dry matter yield determined and chemical analyses carried out. Chemical tests for all the cuttings of the last three years of the experiment were done at the Institute of Technology and Life Sciences in Falenty using near infrared spectroscopy (NIRS) with the Infra Analyzer 450. First of all, the content of total protein and crude fiber was determined.

\section{Weather conditions}

Meteorological data for the years of research were obtained from the Hydrological and Meteorological Station in Siedlce. Sielianinov's hydrometric coefficient (K) was worked out to determine variability of weather conditions and their impact on plant vegetation (Skowera and Puła, 2004).

In the first year (2012) optimal weather conditions, with regard to temperature and rainfall, were only in June and October (Table 3, Fig. 1). In the rest of the growing season, there was not enough rain, with periods of drought and severe drought. In the next years, dry periods were followed by wet periods, with optimal conditions only in April of 2013 and 2014 but also in July of 2014. In each year of the experiment, the best weather conditions were in the first part of the growing season.

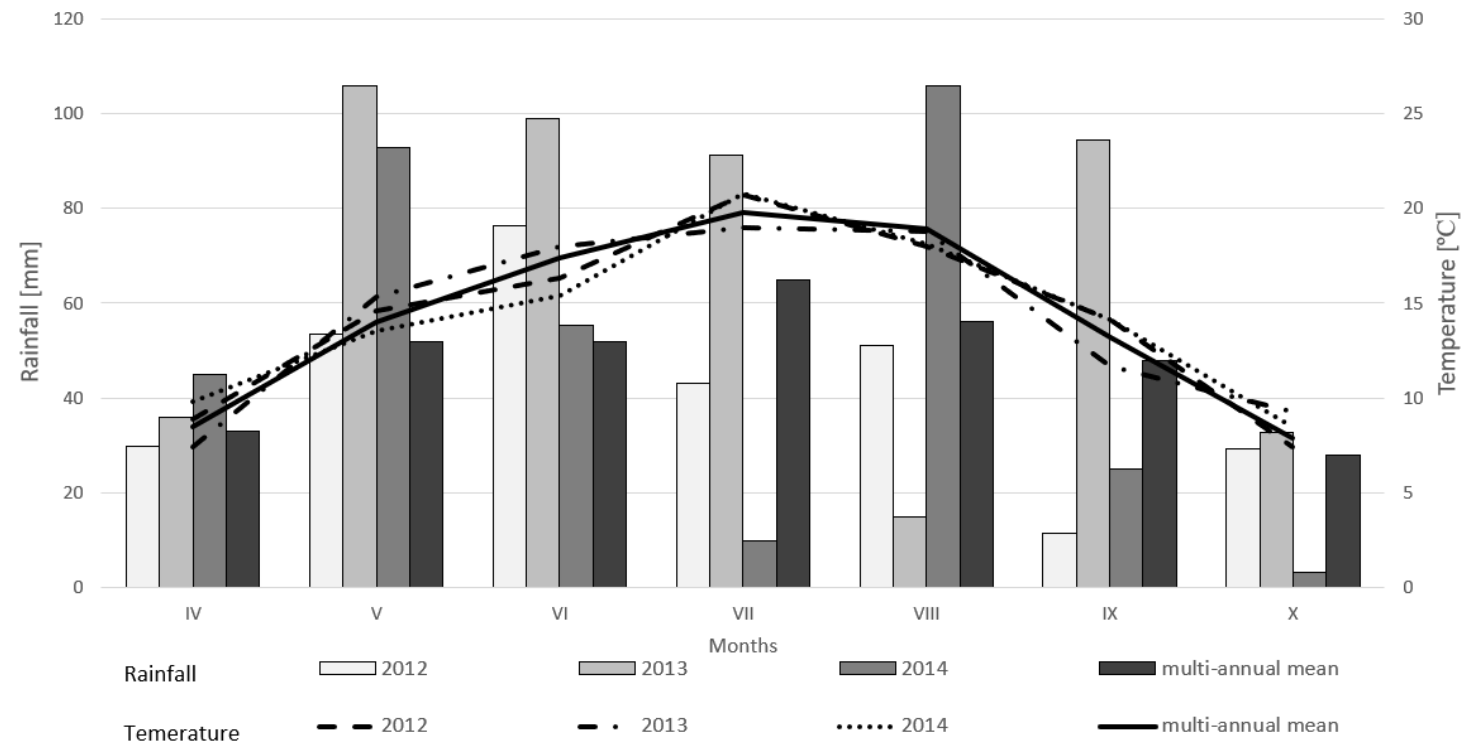

Figure 1. Average of air temperature and sum of atmospheric precipitation in the months of the growing seasons during the research 
Table 3. Sielianinov's hydrometric coefficient $(K)$ values during the growing season

\begin{tabular}{c|c|c|c|c|c|c|c}
\hline \multirow{2}{*}{ Years } & \multicolumn{7}{|c}{ Months } \\
\cline { 2 - 7 } & IV & V & VI & VII & VIII & IX & X \\
\hline 2012 & $1.12(\mathrm{md})$ & $1.22(\mathrm{md})$ & $1.56(\mathrm{o})$ & $0.69(\mathrm{sd})$ & $0.94(\mathrm{~d})$ & $0.27(\mathrm{ed})$ & $1.32(\mathrm{o})$ \\
2013 & $1.60(\mathrm{o})$ & $2.20(\mathrm{w})$ & $1.80(\mathrm{mw})$ & $1.50(\mathrm{o})$ & $0.25(\mathrm{ed})$ & $2.70(\mathrm{sw})$ & $1.22(\mathrm{md})$ \\
2014 & $1.53(\mathrm{o})$ & $2.29(\mathrm{w})$ & $1.20(\mathrm{md})$ & $0.16(\mathrm{ed})$ & $1.95(\mathrm{mw})$ & $0.59(\mathrm{sd})$ & $0.13(\mathrm{ed})$ \\
\hline
\end{tabular}

$\mathrm{K} \leq 0.4$ extreme drought (ed); $0.4<\mathrm{K} \leq 0.7$ severe drought (sd); $0.7<\mathrm{K} \leq 1.0$ drought (d); $1.0<\mathrm{K} \leq$ 1.3 moderate drought (md); $1.3<\mathrm{K} \leq 1.6$ optimal (o); $1.6<\mathrm{K} \leq 2.0$ moderately wet (mw); $2.0<\mathrm{K} \leq$ 2.5 wet (w); $2.5<\mathrm{K} \leq 3.0$ severely wet (sw); $\mathrm{K}>3.0$ extremely wet (ew)

\section{Statistics analysis}

The collected data were analysed statistically using the Statistica 12.0. The mean arithmetic were calculated. Effects of tested factors (grass species, preparations used in experiment, year or cutting) on the content of crude fiber and total protein in plant were estimated using three-way analysis of variance. Detailed comparisons of the mean values were based on Tuckey's test at $p \leq 0.05$.

\section{Results and discussion}

\section{Total protein content}

Total protein content in the grass species tested in the experiment (Tables 4 and 5) varied depending on the fertilizers used, the year of the experiment and the cutting. Generally, no matter what grass species it was, the highest total protein content (Table 4) was in experimental variants where bio products together with mineral fertilizers were applied. The highest content of total protein $\left(158.6 \mathrm{~g} \mathrm{~kg}^{-1}\right)$ was found in the dry matter with Eko-Użyźniacz together with NPK applied. The lowest content of total protein was in grass where the bio product UGmax $\left(127.6 \mathrm{~g} \mathrm{~kg}^{-1}\right)$ was applied. Low content of total protein could be caused by a lack of nitrogen fertilization or by a late harvest. A lot of publications (Valk et al., 2000; Johnson et al., 2001; Tas et al., 2006; Grant et al., 2014) hold that total protein concentration does not always rise with fertilizer doses. Walter (2012) points out that it may be caused by dilution of total protein concentration in the high amount of yield.

Comparing all years of the experiment (Table 4) it was found that no matter what the combination of fertilizers and conditioners was, the highest amount of total protein in dry matter $\left(151.0 \mathrm{~g} \mathrm{~kg}^{-1}\right)$ was found in the second year (2013) of the experiment, with the lowest $\left(141.9 \mathrm{~g} \mathrm{~kg}^{-1}\right)$ in the first year (2012) of the experiment, but these differences were not statistically significant. Differences in total protein concentration were caused through the various weather conditions. In the first year of the research objects contained less total protein, in second year compound content increased when time of the regrowth was moderated by the weather. In the last year in growing season occurred a lot of dry periods, therefore protein content decreased.

In the study, there were no significant differences in total protein content between Dactylis glomerata and Lolium perenne (Table 5). According to Turner et al. (2006b) nitrophilous grass species like Dactylis glomerata, which contains $212 \mathrm{~g}$ of total protein in $1 \mathrm{~kg} \mathrm{DM}$, accumulate the highest amounts of this nutrient. A little less protein is produced by Lolium perenne, with $129 \mathrm{~g}$ in $1 \mathrm{~kg}$ DM. 
Table 4. The effect of fertilizer and the year of the experiment on total protein concentration $\left(\mathrm{g} \mathrm{kg}^{-1}\right)$ in dry matter of the grass species

\begin{tabular}{|c|c|c|c|c|c|c|c|c|c|c|}
\hline \multirow{2}{*}{ Species } & \multirow{2}{*}{ Year } & \multicolumn{8}{|c|}{ Fertilizer } & \multirow{2}{*}{ Mean } \\
\hline & & $\mathbf{0}$ & NPK & UG & $\mathbf{E U}$ & HA & UG+NPK & EU+NPK & HA+NPK & \\
\hline \multirow{3}{*}{$\begin{array}{c}\text { Dactylis } \\
\text { glomerata }\end{array}$} & 2012 & 121.0 & 140.6 & 122.9 & 137.5 & 147.3 & 157.9 & 147.9 & 156.3 & 141.4 \\
\hline & 2013 & 143.8 & 141.3 & 134.2 & 133.8 & 137.8 & 148.6 & 153.7 & 159.7 & 144.1 \\
\hline & 2014 & 149.1 & 141.9 & 144.1 & 155.9 & 159.4 & 159.1 & 161.6 & 150.9 & 152.8 \\
\hline \multirow{3}{*}{$\begin{array}{l}\text { Lolium } \\
\text { perenne }\end{array}$} & 2012 & 126.0 & 142.3 & 109.2 & 137.8 & 132.7 & 153.7 & 174.8 & 161.4 & 142.2 \\
\hline & 2013 & 141.0 & 159.5 & 140.0 & 161.6 & 165.8 & 151.7 & 178.1 & 165.9 & 158.0 \\
\hline & 2014 & 155.0 & 127.6 & 114.8 & 138.9 & 145.5 & 168.7 & 135.2 & 144.5 & 141.3 \\
\hline \multicolumn{2}{|c|}{$\begin{array}{l}\text { Mean effect of } \\
\text { fertilizer }\end{array}$} & 139.4 & 142.2 & 127.6 & 144.3 & 148.1 & 156.6 & 158.6 & 156.5 & \\
\hline \multicolumn{11}{|c|}{ Mean effect of year } \\
\hline \multicolumn{2}{|c|}{2012} & 123.5 & 141.4 & 116.1 & 137.7 & 140.0 & 155.8 & 161.4 & 158.9 & 141.9 \\
\hline \multicolumn{2}{|c|}{2013} & 142.4 & 150.4 & 137.1 & 147.7 & 151.8 & 150.1 & 165.9 & 162.8 & 151.0 \\
\hline \multicolumn{2}{|c|}{2014} & 152.1 & 134.8 & 129.5 & 147.4 & 152.5 & 163.9 & 148.4 & 147.7 & 147.0 \\
\hline
\end{tabular}

$\mathrm{HSD}_{0.05}$ for: fertilizer $=21.9$; year $=$ insignificant; fertilizer/year $=$ insignificant; species/year $=11.0$; species/year/fertilizer $=44.3$

Table 5. The effect of the fertilizer and the cutting on total protein concentration in the dry matter $\left(\mathrm{g} \mathrm{kg}^{-1}\right)$ of grass species (average of the years)

\begin{tabular}{|c|c|c|c|c|c|c|c|c|c|c|}
\hline \multirow{2}{*}{ Species } & \multirow{2}{*}{ Cutting } & \multicolumn{8}{|c|}{ Fertilizer } & \multirow{2}{*}{ Mean } \\
\hline & & $\mathbf{0}$ & NPK & UG & $\mathbf{E U}$ & HA & UG+NPK & EU+NPK & HA+NPK & \\
\hline \multirow{3}{*}{$\begin{array}{l}\text { Dactylis } \\
\text { glomerata }\end{array}$} & $\mathrm{I}$ & 127.7 & 124.0 & 114.2 & 141.0 & 130.6 & 143.9 & 153.9 & 132.6 & 133.5 \\
\hline & II & 134.0 & 142.0 & 142.7 & 142.3 & 156.0 & 163.7 & 153.3 & 167.9 & 150.2 \\
\hline & III & 152.3 & 157.7 & 144.4 & 144.0 & 157.9 & 157.9 & 155.9 & 166.5 & 154.6 \\
\hline \multirow{3}{*}{$\begin{array}{l}\text { Lolium } \\
\text { perenne }\end{array}$} & I & 129.6 & 125.8 & 108.3 & 124.3 & 143.3 & 148.7 & 143.3 & 160.5 & 135.5 \\
\hline & II & 125.1 & 128.1 & 115.6 & 142.5 & 140.2 & 151.6 & 169.7 & 140.5 & 139.2 \\
\hline & III & 167.3 & 175.5 & 140.2 & 171.5 & 160.4 & 173.7 & 175.1 & 170.8 & 166.8 \\
\hline \multicolumn{11}{|c|}{ Mean effect of species } \\
\hline \multirow{2}{*}{\multicolumn{2}{|c|}{$\begin{array}{l}\text { Dactylis glomerata } \\
\text { Lolium perenne }\end{array}$}} & 138.0 & 141.2 & 133.8 & 142.4 & 148.2 & 155.2 & 154.4 & 155.7 & 146.1 \\
\hline & & 140.7 & 143.1 & 121.3 & 146.1 & 148.0 & 158.0 & 162.7 & 157.3 & 147.2 \\
\hline \multicolumn{11}{|c|}{ Mean effect of cutting } \\
\hline \multicolumn{2}{|l|}{ te } & 128.6 & 124.9 & 111.2 & 132.6 & 137.0 & 146.3 & 148.6 & 146.6 & 134.5 \\
\hline \multicolumn{2}{|c|}{ II } & 129.5 & 135.0 & 129.1 & 142.4 & 148.1 & 157.7 & 161.5 & 154.2 & 144.7 \\
\hline \multicolumn{2}{|c|}{ III } & 159.8 & 166.6 & 142.3 & 157.7 & 159.2 & 165.8 & 165.5 & 168.6 & 160.7 \\
\hline
\end{tabular}

$\mathrm{HSD}_{0.05}$ for: species = insignificant; cutting $=8.7$; fertilizer/species $=$ insignificant; fertilizer/cutting $=$ insignificant; species/cutting $=10.8 ;$ species/cutting/fertilizer $=39.8$

As a result of application of mineral fertilization and type of soil conditioner together, was observed increase in total protein content in the both species of grass (Table 5).

Concerning total protein content in individual cuttings (Table 5), was significantly differentiated. The grass of the third cutting contained the highest concentration of 
protein $\left(160.7 \mathrm{~g} \mathrm{~kg}^{-1}\right)$, while the lowest was in the grass of the first cutting $\left(134.5 \mathrm{~g} \mathrm{~kg}^{-1}\right)$. The difference between following cutting was approximately 7 to $11 \%$. Despite of dry period before third cutting, content of total protein in grass was high. It could be caused through the concentration of total protein in mass of grass. Pontes et al. (2007) come up with different results when protein concentration in the biomass of Dactylis glomerata and Lolium perenne was the highest in the second and third cutting and was the lowest in the first cutting (Table 5).

\section{Crude fiber content}

The concentration of crude fiber was not significantly varied depending on the dose of fertilizers (Table 6). However, in data was observed decrease of crude fiber content in the Humus Active Papka plot and Humus Active with mineral fertilization plot approximately 4 to $6 \%$ relative to the control object. On the others experimental objects crude fiber content was similar to the control plot.

Comparing experimental years (Table 6) it was found that no matter what fertilizers were used and which species of grass was tested, the highest concentration of crude fiber $\left(230.9 \mathrm{~g} \mathrm{~kg}^{-1}\right)$ was in the grass of the last year (2014) and the lowest $\left(212.1 \mathrm{~g} \mathrm{~kg}^{-1}\right)$ in the second year (2013) of the experiment. There was a statistically significant difference between crude fiber concentrations in each year. Variable content of crude fiber in the years 2012-2014 was caused through the difference in weather conditions, where in the last one year dry period could caused significant increase of this factor.

Table 6. The effect of the fertilizer and the experimental year on crude fiber concentration ( $g$ $\mathrm{kg}^{-1}$ ) of grass species

\begin{tabular}{|c|c|c|c|c|c|c|c|c|c|c|}
\hline \multirow{2}{*}{ Species } & \multirow{2}{*}{ Year } & \multicolumn{8}{|c|}{ Fertilizer } & \multirow{2}{*}{ Mean } \\
\hline & & $\mathbf{0}$ & NPK & UG & $\mathbf{E U}$ & HA & UG+NPK & EU+NPK & HA+NPK & \\
\hline \multirow{3}{*}{$\begin{array}{l}\text { Dactylis } \\
\text { glomerata }\end{array}$} & 2012 & 261.4 & 250.7 & 265.4 & 250.6 & 227.5 & 231.1 & 257.7 & 227.5 & 246.5 \\
\hline & 2013 & 223.6 & 226.5 & 251.8 & 233.4 & 245.1 & 248.6 & 221.9 & 207.3 & 232.3 \\
\hline & 2014 & 249.3 & 243.1 & 243.1 & 238.4 & 222.2 & 231.7 & 236.7 & 244.4 & 238.6 \\
\hline \multirow{3}{*}{$\begin{array}{c}\text { Lolium } \\
\text { perenne }\end{array}$} & 2012 & 208.3 & 217.3 & 189.6 & 152.8 & 192.6 & 175.3 & 189.0 & 184.8 & 188.7 \\
\hline & 2013 & 171.5 & 201.2 & 211.6 & 183.9 & 192.0 & 202.0 & 194.8 & 177.2 & 191.8 \\
\hline & 2014 & 213.8 & 260.1 & 269.5 & 195.7 & 195.8 & 210.1 & 233.3 & 207.3 & 223.2 \\
\hline \multicolumn{2}{|c|}{$\begin{array}{l}\text { Mean effect of } \\
\text { fertilizer }\end{array}$} & 221.4 & 233.2 & 238.5 & 209.2 & 212.6 & 216.5 & 222.3 & 208.1 & \\
\hline \multicolumn{11}{|c|}{ Mean effect of year } \\
\hline \multicolumn{2}{|c|}{2012} & 234.9 & 234.0 & 227.5 & 201.7 & 210.1 & 203.2 & 223.4 & 206.1 & 217.6 \\
\hline \multicolumn{2}{|c|}{2013} & 197.6 & 213.9 & 231.7 & 208.7 & 218.6 & 225.3 & 208.4 & 192.3 & 212.1 \\
\hline \multicolumn{2}{|c|}{2014} & 231.6 & 251.6 & 256.3 & 217.0 & 209.0 & 220.9 & 235.0 & 225.9 & 230.9 \\
\hline
\end{tabular}

$\mathrm{HSD}_{0.05}$ for: fertilizer $=$ insignificant; year $=15.5$; fertilizer/year $=$ insignificant; species/year $=14.1$; species/year/fertilizer $=57.9$

The study showed significant interaction between such variants as fertilizers, grass species and experimental years. Taking into account both different fertilizers and experimental years (Table 6 ) it was found that the highest concentration of crude fiber was in Dactylis glomerata $\left(265.4 \mathrm{~g} \mathrm{~kg}^{-1}\right.$ ) in the first year (2012) with the UGmax soil 
conditioner applied, and in Lolium perenne the highest concentration $\left(269.5 \mathrm{~g} \mathrm{~kg}^{-1}\right)$ was also in the plot with the UGmax but in the last year (2014) of the experiment.

Comparing both grass species (Table 7) it was found that no matter what fertilizers were applied Dactylis glomerata had a higher concentration of fiber than Lolium perenne (239.1 $\mathrm{g} \mathrm{kg}^{-1}$ and $201.3 \mathrm{~g} \mathrm{~kg}^{-1}$, respectively). The difference between crude fiber concentrations was statistically significant. Tendency to accumulate of crude fiber in Dactylis glomerata species is widely documented in the literature (Ates and Tekeli, 2005; Skládanka et al., 2008; Tilvikiene et al., 2014).

Table 7. The effect of the fertilizer and the cutting on crude fiber concentration $\left(\mathrm{g} \mathrm{kg}^{-1}\right)$ of grass species

\begin{tabular}{|c|c|c|c|c|c|c|c|c|c|c|}
\hline \multirow{2}{*}{ Species } & \multirow{2}{*}{ Cutting } & \multicolumn{8}{|c|}{ Fertilizer } & \multirow{2}{*}{ Mean } \\
\hline & & $\mathbf{0}$ & NPK & UG & $\mathbf{E U}$ & HA & UG+NPK & EU+NPK & HA+NPK & \\
\hline \multirow{3}{*}{$\begin{array}{l}\text { Dactylis } \\
\text { glomerata }\end{array}$} & I & 279.0 & 275.8 & 279.4 & 249.9 & 244.9 & 251.4 & 260.4 & 249.0 & 261.2 \\
\hline & II & 240.6 & 233.4 & 249.0 & 233.8 & 222.2 & 229.7 & 225.6 & 217.5 & 231.5 \\
\hline & III & 214.8 & 211.2 & 231.9 & 238.7 & 227.7 & 230.2 & 230.4 & 212.7 & 224.7 \\
\hline \multirow{3}{*}{$\begin{array}{l}\text { Lolium } \\
\text { perenne }\end{array}$} & I & 186.6 & 258.4 & 253.3 & 215.8 & 196.5 & 215.5 & 226.0 & 195.9 & 218.5 \\
\hline & II & 224.3 & 236.7 & 229.0 & 160.3 & 216.7 & 193.3 & 198.0 & 200.5 & 207.4 \\
\hline & III & 182.8 & 183.5 & 188.4 & 156.3 & 167.3 & 178.6 & 193.1 & 172.9 & 177.9 \\
\hline \multicolumn{11}{|c|}{ Mean effect of species } \\
\hline \multirow{2}{*}{\multicolumn{2}{|c|}{$\begin{array}{c}\text { Dactylis glomerata } \\
\text { Lolium perenne }\end{array}$}} & 244.8 & 240.1 & 253.4 & 240.8 & 231.6 & 237.1 & 238.8 & 226.4 & 239.1 \\
\hline & & 197.9 & 226.2 & 223.6 & 177.5 & 193.5 & 195.8 & 205.7 & 189.8 & 201.3 \\
\hline \multicolumn{11}{|c|}{ Mean effect of cutting } \\
\hline \multicolumn{2}{|c|}{ I } & 232.8 & 267.1 & 266.4 & 232.9 & 220.7 & 233.4 & 243.2 & 222.5 & 239.9 \\
\hline \multicolumn{2}{|c|}{ II } & 232.4 & 235.1 & 239.0 & 197.1 & 219.4 & 211.5 & 211.8 & 209.0 & 219.4 \\
\hline \multicolumn{2}{|c|}{ III } & 198.8 & 197.3 & 210.2 & 197.5 & 197.5 & 204.4 & 211.8 & 192.9 & 201.3 \\
\hline
\end{tabular}

$\mathrm{HSD}_{0.05}$ for: species = insignificant; cutting = insignificant; fertilizer/species = insignificant; fertilizer /cutting = insignificant; species/cutting = insignificant; species/cutting/fertilizer $=53.4$

Content of crude fiber in the both species of grass and the all combinations of fertilizer were not statistically significant. The lowest content of crude fiber in Dactylis glometara was on the plot with the Humus Active Papka with mineral fertilization $226.4 \mathrm{~g} \mathrm{~kg}^{-1} \mathrm{DM}$ (the value $8 \%$ lower than on the control object), while in Lolium perenne biomass from the plot with Eko-Użyźniacz fertilizers $177.5 \mathrm{~g} \mathrm{~kg}^{-1} \mathrm{DM}(11 \%$ lower than on the control object).

Differences between crude fiber content in the cutting was not statistically significant. However, there was seen decreasing trend of crude fiber content from first cutting (239.9 $\mathrm{g} \mathrm{kg}^{-1} \mathrm{DM}$ ) to third cutting (201.3 $\left.\mathrm{g} \mathrm{kg}^{-1} \mathrm{DM}\right)$. Similarly, JankowskaHuflejt and Wróbel (2010) found the lowest concentration of crude fiber in the grass of the third cutting (261.8 $\left.\mathrm{g} \mathrm{kg}^{-1} \mathrm{DM}\right)$, and the highest in the grass from the second cutting (313.7 $\left.\mathrm{g} \mathrm{kg}^{-1} \mathrm{DM}\right)$. Contrary to that Skládanka et al. (2008) found that crude fiber concentration in the biomass of Dactylis glomerata was the highest in the third cutting and successively increased in the following cuttings. Large variety of crude fiber content in the cuttings between literature and this publication was probably caused by differences in hydro-thermal conditions of the weather. 


\section{Conclusions}

1. For both grass species Eko-Użyźniacz applied together with mineral fertilizers increased protein content in fodder.

2. Application of Humus Active Papka with mineral fertilizers lowered crude fiber concentration in fodder.

3. The highest concentration of total protein was in Dactylis glomerata and Lolium perenne from the plots where soil conditioners together with mineral fertilizers were applied.

4. The highest concentration of crude fiber was in Dactylis glomerata growing on the plot with Humus Active Papka together with mineral fertilizers applied, while in Lolium perenne on the plot with Eko-Użyźniacz applied, without mineral fertilizers.

5. Taking into account the studied grass species and fertilizer combinations, Lolium perenne had better quality parameters than Dactylis glomerata, especially fertilized with EU+NPK or HA+NPK. Therefore, the species of this grass fertilized with these fertilizers should be recommended in agricultural practice.

\section{REFERENCES}

[1] Arzani, H., Zohdi, M., Fish, E., Zahedi Amiri, G. H., Nikkhah, A., Wester, D. (2004): Phenological effects on forage quality of five grass species. - Journal of Range Management 57: 624-929.

[2] Ates, E., Tekeli, A. S. (2005): Forage quality and tetany potential of orchardgrass (Dactylis glomerata L.) and white clower (Trifolium repens L.) mixtures. - Cuban Journal of Agricultural Scicience 39(1): 97-102.

[3] Billman, E. D., Goff, B. M., Baldwin, B. S., Prince, K., Phillips, T. D. (2017): Effects of vegetative cool-season grasses on forage removal by dairy heifers. - Agronomy Journal Abstract - Crop Economics, Production \& Management 109(4): 1540-1550. https://doi.org/10.2134/agronj2016.10.0598.

[4] Bumane, S. (2010): The influence of NPK fertilization on Lolium perenne L. forage quality. - Agronomy Research 8: 531-536.

[5] Cullen, B. R., Bullen, D., Hutcheson, C., Jacobs, J. L., Deighton, M. H. (2017): Changes in nutritive characteristics associates with plant heigh, and nutrient selection by dairy cowa grazing four perennial pasture grasses. - Animal Production Science 57(7): 13921397. https://doi.org/10.1071/AN16481.

[6] Ellis, J. L., Dijkstra, J., Bannink, A., Parsons, A. J., Rasmussen, S., Edwards, G. R., Kebreab, E., France, J. (2011): The effect of high-sugar grass on predicted nitrogen excretion and milk yield simulated using a dynamic model. - Journal of Dairy Science 94(6): 3105-3118. https://doi.org/10.3168/jds.2010-4059.

[7] French, K. E. (2017): Species composition determines forage quality and medicinal value of high diversity grasslands in lowland England. - Agriculture, Ecosystems and Environment 241: 193-204. https://doi.org/10.1016/j.agee.2017.03.012.

[8] Grant, K., Kreyling, J., Dienstbach, L. F. H., Beierkuhnlein, C., Jentsch, A. (2014): Water stress due to increased intra-annual precipitation variability reduced forage yield but raised forage quality of a temperate grassland. - Agriculture, Ecosystems \& Environment 186(15): 11-22. https:// /doi.org/10.1016/j.agee.2014.01.013.

[9] Grygierzec, B. (2012): The content of basic nutrients and fiber fractions in hay from extensively used Alopecuretum pratensis and Holcetum lanati communities. - Grassland Science in Poland 15: 53-65 (in Polish). 
[10] Heinsoo, K., Melts, I., Sammul, M., Holm, B. (2010): The potential of Estonian seminatural grasslands for bioenergy production. - Agriculture, Ecosystems \& Environment 137(1-2): 86-92. https://doi.org/10.1016/j.agee.2010.01.003.

[11] Jankowska-Huflejt, H., Wróbel, B. (2010): Evaluation of influence of fertilization with menure on the nutritive value of meadow sward and their usefulness to silage production. - Journal of Research and Application in Agricultural Engineering 55(3): 133-136 (in Polish).

[12] Johnson, C. R., Reiling, B. A., Mislevy, P., Hall, M. B. (2001): Effects of nitrogen fertilization and harvest date on yield, digestibility, fiber, and protein fractions of tropical grasses. - Journal of Animal Science 79: 2439-2448.

[13] Jones, G. B., Alpuerto, J. B., Tracy, B. F., Fukao, T. (2017): Physiological effect of cutting high and high temperature on regrowth vigor in Ochardgrass. - Frontiers in Plant Science 8: 805. https://doi.org/10.3389/fpls.2017.00805.

[14] Loaiza, P., Balocchi, O., Lopez, I. (2017): Changes in water-solble carbohydrates relative to crude protein in perennial ryegrass in response to defoliation frequency. - Grassland Science 63(3): 159-168. https://doi.org/10.1111/grs.12166.

[15] Mertens, D. R. (2002): Gravimetric determination of amylase-treated neutral detergent fiber in feeds with refluxing in beakers or crucibles: collaborative study. - Journal of AOAC International 85(6): 1217-1240.

[16] Peeters, A. (2008): Challenges for grasslands, grassland-based system and their production potential in Europe. Biodiversity and animal feed. - Grassland Science in Europe 13: 9-24.

[17] Pontes, L. S., Carre're, P., Andueza, D., Louault, F., Soussana, J. F. (2007): Seasonal productivity and nutritive value of temperate grasses found in semi-natural pastures in Europe: responses to cutting frequency and $\mathrm{N}$ supply. - Grass and Forage Science 62: 485-496.

[18] Pozdisek, J., Loucka, R., Machacova, E. (2003): Digestibility and nutrition value of grass silages. - Czech Journal of Animal Science 48(9): 359-364.

[19] Robins, J. G., Lovatt, J. A. (2016): Cultivar by environment effects of perennial ryegrass cultivars selected for high water soluble carbohydrates manager under differing precipitation levels. - Euphytica 208(3): 571-581.

[20] Skládanka, J., Dohnal, V., Ježková, A. (2008): Fiber and ergosterol contents in forage of Arrhenatherum elatius, Dactylis glomerata and Festulolium at the end of the growing season. - Czech Journal of Animal Science 53(8): 320-329.

[21] Skowera, B., Puła, J. (2004): Pluviometric extreme conditions in spring season in Poland in the years 1971-2000. - Acta Agrophysica 3(1): 171-177 (in Polish).

[22] Sosnowski, J. (2012): Reaction of Dactylis glomerata L. Festuca pratensis Huds. and Lolium perenne L. to microbiological fertilizer and mineral fertilization. - Acta Scientarum Polonorum, Agricultura 11(1): 91-98.

[23] Sosnowski, J. Jankowski, K. (2015): The applicability of soil's fertilizers in increasing of production effects in Lolium perenne and Lolium multiflorum cultivation. - Journal of Life Science 9: 91-94. https://doi.org/10.17265/1934-7391/2015.03.001.

[24] Sosnowski, J., Jankowski, K., Kolczarek, R., Wiśniewska-Kadżajan, B. (2014): Effect of soil amendment in the cultivation of selected grass species. The future of European grassland. - Grassland Science in Europe 19: 407-410.

[25] Stewart, A. V., Ellison, N. V. (2011): Dactylis. - In: Kole, C. (ed.) Wild Crop Relatives: Genomic and Breeding Resources, 2. ed., pp. 73-87. Springer, New York. https://doi.org/10.1007/978-3-642-14255-0_5.

[26] Systematics of Polish Soil (2011). Without title. - Annals of Soil Science 62(3): 1-193.

[27] Tas, B. M., Taweel, H. Z., Smit, H. J., Elgersma, A., Dijkstra, J., Tamminga, S. (2006): Effects of perennial ryegrass cultivars on milk yield and nitrogen utilization in grazing dairy cows. - Journal of Dairy Science 89: 3494-3500. 
[28] Tilvikiene, V., Kadziuliene, Z., Dabkevicius, Z., Sarunaite, L., Slepetys, J., Pociene, L., Slepetiene, A., Ceceviciene, J. (2014): The yield and variation of chemical composition of cocksfoot biomass after five years of digestate application. The Future of European Grasslands. - Grassland Sciences in Europe 19: 468-470.

[29] Truba, M., Wiśniewska-Kadżajan, B., Sosnowski, J., Malinowska, E., Jankowski, K., Makarewicz, A. (2017): The effect of soil conditioners on cellulose, hemicellulose, and the ADL fiber fraction concentration in Dactylis glomerata and Lolium perenne. Journal of Ecological Engineering 18(1): 107-112. https://doi.org/ $10.12911 / 22998993 / 66249$.

[30] Turner, L. R., Donaghy, D. J., Lane, P. A., Rawnsley, R. P. (2006a): Effect of defoliation interval on water-soluble carbohydrate and nitrogen energy reserves, regrowth of leaves and roots, and tiller number of cocksfoot (Dactylis glomerata L.) plants. - Australian Journal of Agricultural Research 57: 243-249. https://doi.org/10.1071/AR05130.

[31] Turner, L. R., Donaghy, D. J., Lane, P. A., Rawnsley, R. P. (2006b): Effect of defoliation management, based on leaf stage, on perennial ryegrass (Lolium perenne L.), prairie grass (Bromus willdenowii Kunth.) and cocksfoot (Dactylis glomerata L.) under dryland conditions. 1. Regrowth, tillering and water-soluble carbohydrate concentration. - Grass and Forage Science 61(2): 164-174. https://doi.org/ 10.1111/j.1365-2494.2006.00523.x.

[32] Valk, H., Leusink-Kappers, I. E., van Vuuren, A. M. (2000): Effect of reducing nitrogen fertilizer on grassland on grass intake, digestibility and milk production of dairy cows. Livestock Production Science 63: 27-38.

[33] Walter, J., Grant, K., Beierkuhnlein, C., Keyling, J., Weber, M., Jentsch, A. (2012): Increased rainfall variability reduces biomass and forage quality of temperate grassland largely independent of mowing frequency. - Agriculture, Ecosystems \& Environment 148: 1-10. https://doi.org/10.1016/j.agee.2011.11.015.

[34] Xiong, Y., Fei, S., Brummer, E. C., Moore, K. J., Barker, R. E., Jung, G., Curley, J., Warnke, S. E. (2006): QTL analyses of fiber components and crude protein in an annual $x$ perennial ryegrass interspecific hybrid population. - Molecular Breeding 18(4): 327-340. https://doi.org/10.1007/s11032-006-9034-1.

[35] Zielińska, K. J., Fabiszewska, A. U., Wróbel, B. (2014): Assessment of the quality of sward from the grasslands of selected organic farms. - Journal of Research and Application in Agricultural Engineering 50(4): 131-136. 